\title{
O olhar gauche de Carlos Drummond de Andrade
}

\author{
Luciana Bessa SILVA ${ }^{1}$
}

Odalice de Castro SILVA ${ }^{2}$

\begin{abstract}
Resumo: Ler Carlos Drummond de Andrade é descobrir um universo de pedras, enigmas, sombras, personagens, amores, reflexões, lições e impurezas. Autor de uma obra imensa e densa foi na poesia que se expressou de forma mais íntima e intensa. Em seu processo de composição, além da técnica literária, da inspiração e da matéria-prima (a palavra), Drummond valeu-se do olhar. O olhar é um trabalho de atenção, seleção e aprofundamento da realidade circundante. Ele é capaz de angustiar, instigar, prender nossa atenção, sobretudo, nos levar a reflexão. Através dele, o poeta procurou desvendar os mistérios da vida humana. Portanto, propomonos a refletir sobre o olhar gauche do poeta em suas obras Alguma Poesia (1930) e Brejo das Almas (1934). Em sua obra de estreia, em tom confessional, o poeta declarou ser gauche, ou seja, torto, esquerdo, marginalizado. Sua declaração tornar-se-ia no decorrer do tempo sua personalidade estética, como assinalou o estudioso Affonso Romano de Sant'Anna. A metodologia desse artigo é bibliográfico-exploratório embasado em estudos de teóricos como Silviano Santiago, José Guilherme Merquior, Rita de Cássia Barbosa, Marilena Chauí entre outros. Portanto, a poesia drummondiana nos faz olhar e admirar um poeta que nasceu gauche, cuja história é mais 'bonita que a de Robinson Crusoé' e cujo verso foi sua 'consolação e sua cachaça'.
\end{abstract}

Palavras-chave: Olhar. Gauche. Poesia.

\section{THE GAUCHE LOOK OF CARLOS DRUMMOND DE ANDRADE}

\begin{abstract}
Reading Carlos Drummond de Andrade means to discover a universe of stones, puzzles, shadows, characters, love affairs, reflections, lessons and impurities. An author of a massive and dense work, it was in poetry that he expressed himself in a more intimate and intense manner. In his writing process, besides the literary technique, inspiration and raw material (the word), Drummond drew on the look. The look is something that requires attention, selection and deepening of the surrounding reality. He is able to grieve, instigate, hold our attention, and especially lead us to reflection. Through it, the poet sought to unravel the mysteries of human life . Thus, we propose to reflect on the gauche look of the poet's works Some Poetry (1930) and Swamp of Souls (1934). In his debut work, in a confessional tone, the poet claimed to be gauche, crooked, uncoventional, marginalized. His statement would become with time its aesthetic personality, as noted by the scholar Affonso Romano de Sant'Anna. The methodology of this paper is based on the literature and exploratory studies of theorists such as Silviano Santiago, José Guilherme Merquior, Rita de Cássia Barbosa, MarilenaChauaí among others. Therefore, drummondian poetry makes us perceive and admire a poet who was born gauche, whose history is more 'beautiful than Robinson Crusoe' and whose verse was his 'consolation and rum'.
\end{abstract}

Keywords: Look. Gauche. Poetry.

\section{INTRODUÇÃO}

\footnotetext{
1 Mestre em Letras pela Universidade Federal do Ceará. Professora de Língua Portuguesa da Faculdade Leão Sampaio (FALS). Rua General Raimundo Teles, nº 14. Bairro: Grangeiro, Crato-Ceará. Fone: (88) 99213568. Contato: bessaluciana@hotmail.com.

2 Pós-doutora pela Universidade Federal da Paraíba, professora de Teoria Literária da Univeridade Federal do (C) Ceará. Avenida da Universidade, 2683 - Bloco Azul. Benfica. $\quad$ Fone $\quad 87876113$ (ocastroesilva@gmail.com)
} 
A poesia drummondiana cantou o tempo presente e os homens presentes ("Mãos dadas"); tornou vivo aqueles que o tempo se encarregou de levar ("A mesa"); registrou encontros e desencontros com outros poetas (“Quintana’s bar”); criou tal como Camões a sua própria máquina (“A máquina do mundo”); confessou-se melancólico ("Estrambote melancólico") além de acrescentar um verso a mais ao soneto, tornando-o gauche; participou de festas juninas (“Quadrilha”); conheceu 'cantos' não muito recomendáveis ("Cabaré mineiro"); exaltou o seu país ("Hino Nacional"); declarou as contradições do amor ("Não se mate"); confessou inúmeros segredos ("Segredo"), bem como se despiu deles ("Poema de sete faces"). Por fim, enfaticamente, explicou "Se meu verso não deu certo, foi seu ouvido que entortou. /Eu não disse ao senhor que sou senão poeta?” (ANDRADE, 2002, p. 36-37). Drummond fez parte de uma geração preocupada em firmar uma identidade genuinamente brasileira.

Sua vasta obra costuma ser dividida pela crítica literária em quatro fases: a fase gauche (consciência e isolamento), fase social, fase filosófica/nominal e a fase de memórias ou uma síntese das anteriores.

Obra de estreia do poetaAlguma Poesia (1930) é, por excelência, um livro modernista marcado pela ironia, senso de humor, o poema-piada, o poema de circunstância e da captura do cotidiano, tornando assunto poético. Aliás, é marcante a transformação do cotidiano em poesia, aquilo que Gilberto Mendonça Teles denominou de "celebração das coisas comuns" (TELES, 1976, p. 15). É no primeiro texto, o ontológico "Poema de Sete Faces", que Drummond inicia sua busca de autodefinição e monta uma espécie de carteira de identidade: canhoto de nascença, expulso do colégio por alegação de "insubordinação intelectual", simpatizante das ideias do Partido Comunista desde que começou a se interessar por política, sempre esteve do lado esquerdo da vida, ou seja, do lado do coração (BARBOSA, 1988).

Brejodas Almas (1934) é visto pela crítica, ora como um prolongamento da obra anterior, ora como uma obra de transição entre a fase irônica e individualista e uma poesia social comprometida iniciada com a publicação de Sentimento do Mundo em 1940.

Para construção de uma obra ímpar na Literatura Brasileira, Drummond valeu-se de um olhar gauche e perspicaz. Isso porque todo poeta é, antes de tudo, um genuíno observador da sociedade. Vasconcellos diz que "não existe observador que não esteja entrando com seus interesses, seus desejos, suas intenções, sua intencionalidade (...) em tudo que ele percebe". (VASCONCELLOS, 2001, p.1)

Diante desse contexto, nos propomos a refletir sobre o olhar gauche do poeta em suas obras Alguma Poesia (1930) e Brejo das Almas (1934). Trata-se de um artigo bibliográfico 
exploratório embasado em estudos de téoricos como Silviano Santiago (2002), José Guilherme Merquior (1976), Antônio Houaiss,Marilena Chauaí (1988) entre outros.

Percebe-se que, através do seu olhar, Drummond pôde captar a si mesmo e o transcurso dos homens, a partir de uma perspectiva gauche, melancólica e irônica.

\section{GAUCHE?}

Afinal, o que significa ser gauche? Para tornar clara a compreensão do termo, buscamos informações em um dicionário francês, onde lemos "coisa defeituosa, atravessada, desviada"(DUBOIS, 1994 , p.821). Ser gauche é ser diferente, esquisito, torto, marginalizado.

Para Câmara Cascudo (1985), a superstição do lado direito e do lado esquerdo do homem é universal. O primeiro lado simboliza o bem, o segundo o mal. Serão agraciados com a justiça, a bondade, a compreensão, a razão, aqueles que estiverem ao lado direito, ao passo que os do lado esquerdo serão amaldiçoados com a injustiça, o infortúnio, a desgraça, a incompreensão. Na poesia drummondiana, o vocábulo esquerdo assume uma conotação negativa.

O poeta, nascido para ser gauche, teve que aprender a conviver com a sina de ser diferente. A trajetória de Drummond foi difícil, árdua e penosa. Acompanhemos, pois, alguns de seus passos.

A gaucherie é notada, na poesia drummondiana, através das referências ao lado esquerdo. Em "Consideração do Poema" (ANDRADE, 2002, p.115), os poetas amados são incorporados ao seu fatal "lado esquerdo"; em "Cemitérios" (ANDRADE, 2002, p.405), o poeta começa a andar de banda, porque "Do lado esquerdo" carrega seus mortos; em "Nos Áureos Tempos" (ANDRADE, 2002, p.136), refere-se ao "lado esquerdo" dos jardins que povoaram sua infância; ao ficcionalizar a "Morte de Neco Andrade" (ANDRADE, 2002, p. 406), narra que o "Cadáver de Neco atravessa canhestramente o segundo ato, da esquerda para a direita"; no poema "A Mesa" (ANDRADE, 2002, p.292-300), pergunta-se "Quem senta do lado esquerdo / assim curvada?”; em "Falta Pouco" (ANDRADE, 2002, p. 697) é demonstrado o "hábito de chegar à janela da esquerda"; em "Campo de Flores" (ANDRADE, 2002, p.268), o amor ofertado recai "na mão esquerda".

O lado esquerdo, referenciado pelo eu lírico, simboliza o "canto" a que fora destinad@ desde seu nascimento, é o lugar onde a dor é a tônica que rege a vida, onde se vê apenas una tonalidade, a noite; onde a alegria é escutar Chopin. Simboliza, igualmente, o lado do coração, 
onde os sentimentos pulsam mais intensamente. Nele [o coração] estão depositadas as cenas e as recordações de fatos e pessoas marcantes na trajetória do gauche.

\section{O OLHAR GAUCHE}

Na produção de uma pintura, de uma escultura, ou de um texto, o olhar do artista é essencial para o processo de criação.Talvez, esse seja um motivo pelo qual o olhar seja conhecido como a "janela da alma". Quando nossos olhos encontram, além de pedras, outros olhos em seu caminho, eis um momento perigoso, pois é chegada a hora de nos despir das máscaras que usamos para nos proteger da realidade.É um momento único, regado de prazer e de perigo. Sim, olhar é perigoso. Através dele passamos a conhecer a vida tal como ela se nos apresenta: caótica. Observemos:

Relatos expressos na Carta de Pêro Vaz de Caminha, documento no qual Caminha registrou as suas impressões sobre a terra e seus habitantes, atestam que houve uma troca de bugigangas entre índios e portugueses. Dentre esses objetos havia espelhos. Acreditamos que nesse momento a ingenuidade indígena começa a se perder como faz alusão a música Índios, de Renato Russo "Nos deram espelhos e vimos um mundo doente". De acordo com a Bíblia judaica, Sodoma e Gomorra são duas cidades que teriam sido destruídas por Deus devido a atos imorais. No livro de Gêneses (versículo 1-3), há o relato de que dois anjos hospedam-se na casa de Ló. Contudo, o povo cerca sua casa para terem relações sexuais com seus dois hóspedes. Os anjos ferem tais homens coma cegueira, retiram o patriarca e sua família da cidade e mandam que sigam em frente e não olhem para trás. Ordem não seguida pela mulher de Ló, que é transformada em uma estátua de sal. Inicia-se, então, a destruição das cidades. Segundo consta na mitologia grega, Narciso, filho do deus rio-Cefiso e da ninfa Liríope era um ser de rara beleza. No dia de seu nascimento, o adivinho Tirésias vaticinou que Narciso contemplasse sua própria beleza. Certa vez, ao contemplar seu reflexo em um lago foi tragado por ela e morreu. Ainda na mitologia grega, há a história de Orfeu, filho da musa Calíope e de Apolo, que se apaixona por Eurídice. Um apicultor chamado Aristeuapaixone por ela. Ao tentar escapar de suas perseguições, ela é picada por uma cobra e morre. Inconformado, Orfeu desce ao "Inferno" para resgatá-la, porém uma condição lhe é imposta: não olhar para ela até que estivesse à luz do sol. O que não aconteceu e Orfeu perde-a pelo seu olhar. Baseadones@ lenda, o poeta Vinícius de Moraescriou a peça Orfeu da Conceição, que estreouono Rio de Janeiro em 1956. No livro de Sófocles, Édipo Rei, o personagem Édipo mata seu pailaioe 
casa-se com sua mãe Jocasta. Quando descobreo que fez, fura seus dois olhos por ter estado cego durante todo esse tempo.

O olhar é um dos poderosos sentidos do homem, porque seduz e, seduzindo, é capaz de devorar a alma humana. É também capaz de sinceridade, quando, olhos nos olhos, expomos nosso íntimo e vemos o do outro.

Mas, o que realmente significa ver? Segundo Marilena Chauí (2003), em análise do assunto, afirma que:

[...] ver é olhar para tomar conhecimento e para ter conhecimento. Esse laço entre ver e conhecer, de olhar que se tornou cognoscente e não apenas espectador desatento, é o que o verbo grego eidô exprime. Eidô - ver, observar, examinar, fazer ver, instruir, instruir-se, informar, perceber - e viso - visar, ir olhar, ir ver, examinar, observar (CHAUI, 2003, p. 31).

Ver é, ainda, postar-se diante dos fatos, refletir, ponderar, perceber, examinar e, só então, expor princípios, valores e sentenças.

A obra de um artista é produto de seu olhar, seu talento e ideologia. Machado de Assis recriou em palavras, com precisão e perícia, a sociedade de seu tempo. Seu olhar sobre seu tempo é irônico, mordaz, implacável e pessimista. A alma humana foi desvendada através de seu olhar. Por isso, é fundamental que os artistas olhem para todas as direções com extrema atenção para conhecer profundamente a matéria que apresentarão ao seu leitor.

O artista é aquele que sente e transforma o que sente a partir de sua visão. Portanto, quando lemos uma obra, em prosa ou em verso, estamos diante do olhar de seu autor. Pelo olhar do artista, o mundo parece mais claro, porque ele procura tornar os fatos invisíveis, visíveis aos nossos olhos. Estes são "faróis emissores de raios luminosos que, deslocandose no espaço, chocam-se com as coisas materiais e esse encontro é responsável pela visão". (CHAUÍ, op. cit., p. 31)

É a visão a usurpadora dos mais recônditos segredos humanos, a responsável por trazêlos à tona. É por ela que as artes humanas são desenhadas aos nossos olhos, espelhos capazes de exteriorizar o nosso interior, pois a "vista é o mais espiritual de todos os sentidos [...] capta as coisas longínquas com extraordinária rapidez e por isso as coisas apreendidas por ela são mais facilmente identificáveis por nós e mais eficazmente as retemos na alma”. (CHAUÍ, id. ibid, p. 31)

O artista é um admirador do Belo. É a captação da beleza que o impele a compor sua obra, porque a visão leva o homem ao conhecimento (do mundo e dele mesmo), apesar de efêmera. Surge, então, a necessidade de torná-la eterna. Para tanto, a linguagem é chamada a rivalizar com a visão. "O pensamento fala com a linguagem do olhar". (CHAUÍ, idemi’, p. 31 )? 
Para a criação do mundo, Deus disse: "Haja luz; e houve luz". Desde então, os nascimentos, são precedidos pela expressão “dar à luz”. (GÊNESIS, 1994, 1:3). Na obra do poeta Carlos Drummond de Andrade, poder-se-ia afirmar, contudo, que o nascimento de Carlos (eu lírico) foi marcado pela falta de luminosidade, uma vez que fora anunciado por um "anjo torto" cujo habitat era coberto pelas "sombras".

Elas serão, assim, as responsáveis por tornar a visão de Carlos turva. Porém, será através do olhar, a janela da alma, que Carlos se utilizará para se comunicar com o mundo. É importante saber que nem sempre ele se valerá do "olhar" para estabelecer essa comunicação. Mas percebemos que o apelo visual, em muitas ocasiões, será o elo entre o eu lírico e o mundo em "Os ombros suportam o mundo".

Ficaste sozinho, a luz apagou-se,

Mas na sombra teus olhos resplandecem enormes.

(ANDRADE, 2002, p. 79-80).

Os versos acima comprovam nossa afirmação e mostram que o anúncio do anjo torto conduzirá o eu lírico à solidão e ao isolamento, fatores que acentuarão, ainda mais, o olhar gauche de Carlos. A temática do olhar inicia-se no "Poema de Sete Faces", onde o eu lírico anuncia um olhar poético, porém, extático e passivo. Ressaltamos que essa visão se altera de acordo com o desenvolvimento do gauche, ou seja, o olhar de Alguma Poesia (1930) difere do de A Rosa do Povo (1945).

$\mathrm{Na}$ primeira fase do olhar drummondiano, observa-se a superficialidade no tratamento dos fatos, a fina ironia, a irreverência e a rebeldia. Consequências de um nascimento marcado pelo signo da torção. Observemos, agora, a terceira estrofe do "Poema de Sete faces":

O bonde passa cheio de pernas: pernas brancas pretas amarelas

Para que tanta perna, meu Deus, pergunta meu coração.

Porem meus olhos não perguntam nada.(ANDRADE, 2002, p. 5).

Santo Agostinho afirmou que "Os olhos amam a beleza e a variedade de formas" (AGOSTINHO, 2002, p. 230). É pelos olhos que a nossa curiosidade é aguçada, porém, a pergunta do eu lírico parte do seu coração, não dos olhos.

Os olhos representam o próprio eu lírico nascido sob a marca da dor e que, ainda, não conseguiu se situar frente ao mundo. A oposição entre o coração e os olhos demonstra o conflito interior/exterior do eu lírico, ou nas palavras de José Guilherme Merquior, aoposição entre "a sensualidade da percepção" e "a pureza de 
(MERQUIOR, 1976, p. 12)

Essa oposição e/ou conflito acontece porque o próprio eu lírico declara ser possuidor de "olhos tortos" (ANDRADE, 2002, p. 996-997). Por conseguinte, os fatos que lhe são apresentados são tortos. Para o poeta Carlos Augusto Viana, "Em Carlos Drummond de Andrade, a ligação com o olhar irá percorrer significativo caminho ao longo de toda a sua obra poética. Olhar funciona como o regulador na relação entre o sujeito e o mundo" (VIANA, 2003, p. 32).

Da mesma forma que alguém perdido numa noite soturna deseja uma lanterna ou uma fogueira para se proteger da escuridão, o gauche, através de seus olhos, procura ver, observar, espiar o mundo para com ele se integrar, ou seja, seus olhos passam a ser, assim, a arma de que se vale o gauchepara deixar de ser marginalizado pela sociedade.

A busca de conhecimento do mundo, o olhar do eu lírico deparar-se-á com a aventura, o encontro com a fantasia e o desconhecido:

a história de Robinson Crusoé

comprida história que não acaba mais.

(ANDRADE, 2002, p. 6).

Como afirmamos anteriormente, essa primeira fase do olhar drummondiano caracterizase pela ironia, irreverência, deboche, mas também pela inocência de quem acaba de nascer. Nessa etapa, observa-se nos versos citados, o eu lírico vê a sua história "mais bonita que a de Robinson Crusoé" entrelaçando-se com a sua. Seus olhos mais tarde o despertarão para outros universos que não o seu próprio. Através deles, seu espírito será tocado e chamado a ver mais longe. Quando isso ocorre, o eu lírico afasta a sombra que o acompanha, se tornando menos individualista e vendo com mais lucidez.

Voltemos à fase irônica e debochada em que,

\author{
Por uma frincha \\ o diabo espreita com o olho torto. \\ Diabo tem uma luneta \\ que varre léguas de sete léguas \\ e tem ouvido fino \\ que nem violino.(ANDRADE, 2002, p. 6-7)
}

O diabo, nesses versos, tem um amplo poder de visão, que através de sua luneta, observa os acontecimentos como um voyeur "que varre léguas". Contrariamente, o eu lírico não possui esse mesmo poder de visão, embora comungue com o diabo de um mesmo "olho torto". 
O gauche e o diabo começam a apresentar características comuns: ambos possuem o "olho torto" e são "voyeurs". Ainda, na última estrofe do "Poema de Sete Fases", o eu lírico confidenciará que a lua e o conhaque o botam "comovido como o diabo". Ao que nos parece, eu lírico vê o gauche como um elemento diabólico. Porém, essa semelhança entre ambos tornará aquele mais sinistro.

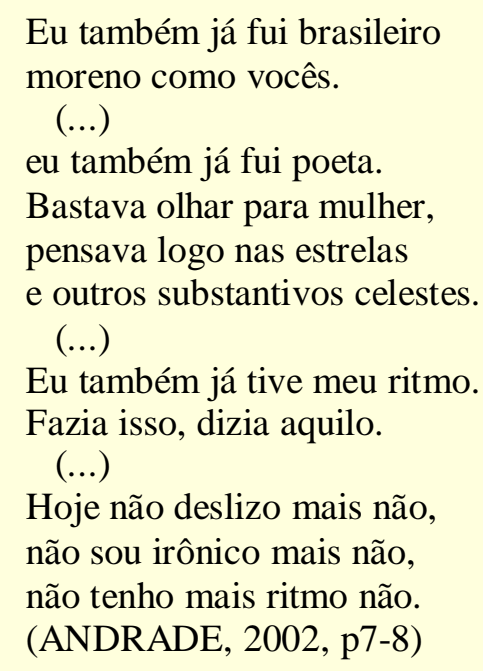

O eu lírico foi, não é. Possuía as mesmas características do brasileiro: olhava para a mulher e arquitetava seu poema, possuía ritmo, mas a gaucherie roubou-lhe o espírito de igualdade.

Depreende-se pela leitura da segunda estrofe, que o olhar é a mola propulsora para o eu lírico assumir a condição do poeta, harmonizar-se com as estrelas e delas retirar a matéria para a composição de seus poemas, "substâncias celestes”. Mas, em se perdendo esse olhar, o poeta confessará: “minha poesia perturbou-se”. Esse fato acarretará imagens dolorosas, ressentidas, rancorosas e amarguradasaos olhos do gauche.

Na primeira estrofe do poema "Europa, Franca e Bahia", o eu lírico, através de seus olhos, confere a beleza da cidade luz uma tonalidade esquisita.

Meus olhos brasileiros sonhando exotismos.

Paris. A torre Eiffel alastrada de antenas como um caranguejo.

Os cais borolentos de livros judeus

e a água suja do Sena escorrendo sabedoria.

(ANDRADE, 2002, p. 9-10)

Novamente, através de uma sinédoque, o eu lírico atribui aos seus olhos a capacidade de sonhar. Por eles, um dos símbolos de beleza do povo francês, a torre Eiffel, assemelha-se a um 
crustáceo de oito patas de aparência estranha. Quanto ao Sena, cuja limpidez e beleza, serviu de inspiração para vários escritores, encontra-se com sua "água suja". Aos olhos do eu lírico, Paris não passa de uma mera pintura exótica.

Porém, algumas telas de palavras expostas na obra drummondiana são de um aspecto grotesco, porque o olho de quem as pintou tem "melancolias" próprias de quem nasceu em solo Itabirense, onde "Os homens olham para o chão" (ANDRADE, 2002, p. 10-13). Esse solo apresenta,

Noventa por cento de ferro nas calcadas.

Oitenta por cento de ferro nas almas.

(ANDRADE, 2002, p. 68).

Ressaltamos que a Terra natal do poeta, Itabira do Mato Dentro, ficou conhecida e famosa por suas minas de ourolevando A Companhia Vale do Rio Doce a explorá-las e quase levá-las à extinção.

O olhar do poeta voltado para o ferro das calçadas acabou contaminando sua alma e seus olhos. Essa "visão para baixo" foi estudada pelo crítico Roger Bastide, que assim se expressou:

\footnotetext{
Sua visão, principalmente nos primeiros poemas, é uma visão não para o alto, mas sim, para baixo. O mundo que lê apresenta é o mundo da terra, das pedras: "no meio do caminho tinha uma pedra" - das calçadas, dos velhos porões das casas; e o que ele vê nas pessoas são pernas. (BASTIDE, 1997, p.78).
}

Nascer sob o signo da torção privou o eu lírico de olhar para cima, olhos nos olhos. Ele vê, por exemplo, o bonde "cheio de pernas: / pernas brancas pretas amarelas" (ANDRADE, 2002, p. 5), mas não consegue divisar seus rostos, o seu olhar e, assim, a comunicação não se estabelece. Ele fica, dessa forma, no seu canto reduzido a uma condição inferior, sem interferir nos acontecimentos.

O sentimento de exclusão do eu lírico leva-o a manifestar certo cansaço em sua visão, devido às pedras encontradas em seu caminho:

Nunca me esquecerei desse acontecimento na vida de minhas retinas tão fatigadas.

(ANDRADE, 2002, p. 16).

Sete faces, sete pedras, nascimento vaticinado por um "anjo torto", exclusão social, desarmonia com o mundo são alguns dos acontecimentos que tornaram fatigadas as retinas do eu lírico. Tanto cansaço impede que seus olhos vejam o "mar", aquele que é bonito, brav@ que guarda as lágrimas das musas e das mães, que viram seus filhos partirem $e_{\odot}$ não 
retornarem. Não só o cansaço dificulta que o mar seja visto. Ele exige de seu espectador um olhar grandioso, pungente, capaz de tragá-lo em toda a sua essência.

O eu lírico dessa fase não é capaz de tal feito, por isso, o mar será substituído pela lagoa, que, além de grande, é calma e brilha.

Enquanto as retinas do eu lírico permanecem fatigadas, ele transfere seu olhar aos objetos, personificando-os. No "Poema de Sete Faces" (ANDRADE, 2002, p. 5), por exemplo, “As casas espiam os homens”e, em, “Cidadezinha Qualquer” (ANDRADE, 2002, p. 23) "Devagar ... as janelas olham".

O olhar drummondiano assume em "O Sobrevivente"um ar pessimista, desesperançoso e amargurado.

Os homens não melhoram e matam-se como percevejos.

Os percevejos heroicos renascem.

Inabitável, o mundo é cada vez mais habitado.

E se os olhos reaprendessem a chorar seria um segundo dilúvio.

(ANDRADE, 2002, p. 26-27)

Esses sentimentos são de quem vê os homens se digladiando e reduzidos à condição de animais (irracionais). Porém, os "percevejos" renascem, o homem não, desarticulando tal expectativa da vida animal. O mundo, com quem o eu lírico procura harmonizar-se, encontrase cada vez mais inabitável (de homens) e habitável (de percevejos). Em meio a tanta mutilação, o eu lírico julga-se um sobrevivente pessimista, que não acredita na capacidade do homem de se comover ante essa situação de miséria. $\mathrm{O}$ ferro do chão de Itabira petrifica o coração do eu lírico.

Em "Moça e Soldado" o eu lírico não olha, espia:

Meus olhos espiam

a rua que passa.

(...)

Meus olhos espiam

as pernas que passam.

$$
\text { (...) }
$$

Meus olhos espiam.

Tambores, clarins

e pernas que passam.

Meus olhos espiam

espiamespiam

soldados que marcham

moças bonitas

soldados barbudos

... para namorar,

para brigar.

Só eu não brigo.

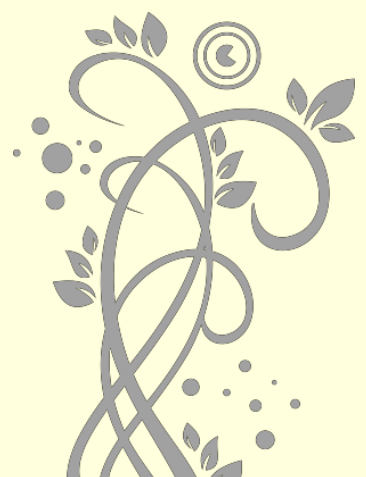


O termo espiar, repetido sete vezes ao longo do poema em estudo, adequa-se ao gauche, uma vez que espiar é próprio de quem está à espreita dos acontecimentos. Nesse ato de espionagem empreendido pelo gauche ele observa a "rua", as "mulheres", os "soldados", as “pernas", os "tambores”, os "clarins" que passam. É então que se apercebe que só seus olhos permanecem extáticos.

É espiando os outros que o eu lírico vê a si próprio como um ser esquisito.

\author{
Moça bonita foi feita para \\ namorar. \\ Soldado barbudo foi feito para \\ brigar. \\ (...) \\ Só eu não brigo. \\ Só eu não namoro. \\ (ANDRADE, 2002, p. 27-28)
}

A moça bonita está para o namoro, assim como o soldado barbudo para a briga; o eu lírico para a marginalização.

Na poesiadrummondianahá também adescriçãoda trajetória de uma família mineira, a “Sesta" (ANDRADE, 2002, p. 33-34). O olhar da família mineira é de desespero e privação. Quando olham para o céu, imaginamos um olhar voltado para Deus, mas o que observam é tão somente "o cacho de bananas". A miséria parece consumir de tal forma a famíliaque há um certo momento em que
Os olhos se perdem,
na linha ondulada
do horizonte próximo (a cerca
da horta). (ANDRADE, 2002,
p. 33-34).

A fome acaba dificultando a visão da família e o seu olhar toma outros rumos: "A família mineira / olha para dentro" (ANDRADE, 2002, p.33-34) e procura em seu interior o que fora não encontra.

O olhar de Alguma Poesia repousa nas sombras, então notamos a presença da superficialidade, do deboche, do cansaço, da amargura. Porém, a sombra presentificada no começo da obra desaparece (não por completo) como um passe de mágica. Observemos o que diz uma das estrofes do Poema da Purificação:

Mas uma luz que ninguém soube

dizer de onde tinha vindo apareceu para clarear o mundo, 
A luz surge no final da obra de estreia do poeta de forma inexplicável. A sombra vem para "clarear o mundo" tornando-o um lugar harmônico e habitável em que o eu lírico deixe de com ele rivalizar.

Em 1934, com a publicação de Brejo das Almas, o poeta mantém a atitude individualista e seu olhar gauche continua centrado em si mesmo.

O ar de abandono expresso pelo eu lírico, em Alguma Poesia (1930), quinta estrofe do "Poema de Sete Faces" é o mesmo encontrado em "Um Homem e Seu Carnaval", de Brejo das Almas. Vejamos

\author{
Deus me abandonou \\ no meio da orgia \\ entre uma baiana e uma egípcia. \\ Estou perdido sem olhos, sem boca \\ sem dimensões. \\ As fitas, as cores, os barulhos \\ passam por mim de raspão. \\ Pobre poesia.
}

(ANDRADE, 2002, p. 46)

Abandonado, o eu lírico encontra-se "sem olhos" e "sem boca", portanto, "sem dimensões". A falta daqueles o impedirá de ver "as cores" que acrescentariam certo brilho e um certo charme aos seus poemas, condenando-o a desviar das "fitas", das "cores", do "barulho", ou seja, a não fazer uso de certos apetrechos responsáveis por servir como acabamento para seus poemas. Através de seu olhar, o eu lírico perceberá que produz uma "Pobre poesia".

Os sentimentos de Carlos (eu lírico) parecem não ter sofrido alterações de Alguma Poesia a Brejo das Almas. Primeiramente, o eu lírico expressa seu olhar abandonado, agora, ele insiste em olhar para baixo:

\footnotetext{
Amor, a quanto me obrigas.

De dorso curvo e olhar aceso, troto as avenidas neutras atrás da sombra que me inculcas.

(ANDRADE, 2002, p. 54-55).
}

“O Procurador do Amor" encontra-se obrigado a andar de "dorso curvo" e de "olhar aceso". Cousas do amor, sentimento contraditório, tal como a postura desse amante, pois se o 
seu olhar é claro, seu dorso deveria buscar o alto e não se voltar para baixo, uma postura gauche que se explica, talvez, pela procura de uma "sombra". Enquanto não conseguir se desvincular dela, o eu lírico persistirá de "dorso curvo".

Nascer e viver sob o véu opaco e fechado foi a sina daquele cujo "dorso curvo" o impediu de encontrar o amor. Restou-lhe apenas uma "Coisa Miserável”, a necessidade de clemência através dos "olhos misericordiosos" do Senhor. Eis então que lhe brotam um sentimento de revolta e total desespero.

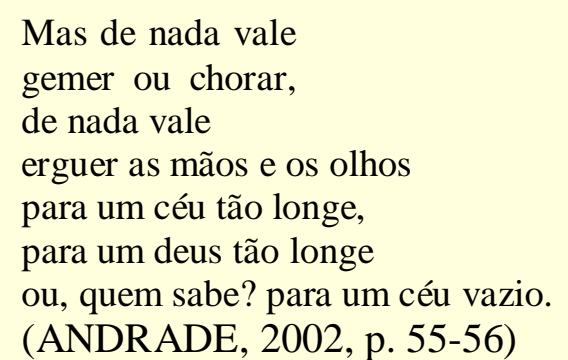

Para o gauche cético, a misericórdia não cobrirá sua postura torta, pois mesmo que suas "mãos" e seus "olhos" estejam voltados para o "céu", este se encontra "tão longe" e seu habitante, "deus", está grafado em letra minúscula para expressar sua dor e reduzi-lo à condição inferior e comprovar mais uma vez sua gaucherie. Na última estrofe, o eu lírico põe em dúvida que o céu esteja habitado. Sua torção é tamanha que ele acredita na possibilidade de estar erguendo suas "mãos" e seus "olhos" em vão para um "céu vazio", consequentemente, sem Deus.

O ceticismo imanente a Carlos (eu lírico) contagia a todos que estão ao seu redor. Nem mesmo o amor consegue escapar:

Cantiga do amor sem eira

nem beira,

vira o mundo de cabeça

para baixo.

Suspende a saia das mulheres

Tira os óculos dos homens,

$\mathrm{O}$ amor, seja como for,

é o amor

(...)

Daqui estou vendo o amor

irritado, desapontado, mas também vejo outras coisas:

vejo beijos que se beijam, ouço mãos que se conversam

e que viajam sem mapa.

Vejo muitas outras coisas que não ouso compreender...

(ANDRADE, 2002, p. 46-48) 
O amor é visto como um sentimento capaz de desnortear o homem, deixando-o de "cabeça para baixo" e tirando-lhe os óculos, ou seja, deixando-o cego. Um homem sem direção é capaz de cometer qualquer tipo de atrocidades, um homem sem visão é um condenado a caminhar pelo mundo das trevas dependendo dos outros, ou, ainda, considerado um fardo, devendo ficar à margem dos acontecimentos.

Até mesmo no amor, o eu lírico não consegue manter olhos nos olhos. Em sua visão, o amor é "irritado", “desapontado". Consequência de seus "olhos tortos”. Há outras coisas referentes ao amor como "corpos", "almas", "mãos" que se entrelaçam, mas, nesse momento, eles viajam "sem mapa" e o eu lírico não consegue mais vê-los. Há outras coisas, porém, que não são suscetíveis de explicação como a gaucherie que lhe é inerente. Estas coisas ele não ousa compreender. E o enigma permanece.

Embora o olhar de Carlos (eu lírico) permaneça centrado em sua torção, embora a tonalidade escura cubra seu caminho, embora a sombra de Alguma Poesia esteja presente em Brejo das Almas, no seu penúltimo poema, "Castidade", a luz queno fim da obra anterior já se fez notar, ressurge com mais intensidade.

O perdido caminho, a perdida estrela que ficou lá longe, que ficou no alto, surgiu novamente brilhou novamente como o caminho único, a solitária estrela.

(...)

De novo a estrela brilhara, mostrando o perdido caminho da perdida inocência. E eu irei pequenino, irei luminoso conversando anjos que ninguém conversa. (ANDRADE, 2002, p. 62-63).

Sinônimo de brilho, de esplendor, de fagulha, a estrela "que ficou lá longe", no nascimento do eu lírico, surge e brilha novamente permitindo-lhe ver "perdido caminho" que roubou sua "inocência". A partir dessa centelha, o eu lírico segue "luminoso" a sua trajetória, porém com os "anjos". Ao que tudo indica não se trata de um anjo à esquerda do Senhor.

\section{CONSIDERAÇÕES FINAIS}

Cada escritor de seu jeito de ser, de sentir, de escrever e, claro, seu modo de olhar para si e para o outro. Para olhar é necessária uma atenção especial, um compromisso, uma 
responsabilidade e uma contemplação. Olhamos como o propósito de ir sempre mais além. Por isso, que o verbo olhar é complementado pelo verbo ver, ou seja, para olhar é preciso, antes, ver. O olhar é perceptivo e existencial. O olhar é capaz de angustiar, instigar, prender nossa atenção, provocar reações diversas. O olhar nos leva a reflexão.

Drummond é um desses poetascujo olhar captou o fazer poético demodointenso, simples, irônico e confessional. O poema foi para Drummond primazia: da declaração do amor à reflexão sobre o mundo ameaçado pela tecnologia; da nostalgia da terra à lembrança dos poucos amigos; do medo dos monstros cultivados na infância à ironia das convenções sociais; da saudade da mãe à indignação provocada pela injustiça social; do encanto das primeiras leituras ao protesto pela desordem do mundo. (BARBOSA, 1988)

Sua visão lhe fez verque sua melhor arma era a palavra, sua companheira inseparável. Através dela, denunciou e criticou a sociedade de seu tempo, convidou seus companheiros a caminharem de "mãos dadas", descreveu a família mineira, retratou a solidão do homem nas grandes metrópoles, criou máscaras para se proteger de certos horrores, exaltou o Brasil, cantou amores, escondeu segredos, descobriu que seu coração era menor do que o mundo e que precisava de todos para sobreviver.

Por fim, vale salientar que o olhar drummondiano é diferenciado, pois é gauche, ou seja, torto, esquerdo, marginalizado. Mas foi, justamente, seu modo de ver a si, ao outro e sua poética que o tornou um dos maiores poetas da Literatura Brasileira.

\section{REFERÊNCIAS}

ANDRADE, Carlos Drummond de. Poesia completa. Rio de Janeiro: Editora Nova Aguilar, 2002.

AGOSTINHO, Santo. Confissões. São Paulo. Ed. Martin Claret, 2002.

BARbOSA, Rita de Cássia. Carlos Drummond de Andrade. 2 ed. São Paulo: Ed. Nova Cultural, 1988 (Literatura comentada)

BALBO, Wellington. A lenda de narciso. Disponível em: www.recanto das letras. Com.br. Acessado em 20/08/2014.

BATISDE, Roger. Poetas do Brasil. São Paulo: Editora de São Paulo; Duas cidades, 1997.

BÍBLIA SAGRADA. Trad: João Pereira de Almeida. Sociedade Bíblica do Brasil. São Paulo 1994. 
CASCUDO, Câmara. Superstição do Brasil. São Paulo: Ed. Itatiaia, 1985.

CAMINHA, Pêro Vaz de. A carta. Disponível em http://www.dominiopublico.gov.br/download/texto/ua000283.pdf. Acessado em 20/08q2014.

DUBOIS, Jean. Dictionaire de la langue française: lexis. Paris : Larousse, 1994.

MERQUIOR, José Guilherme. Da "vida besta" ao sentimento do mundo. In: Verso Universo em Drummond. Rio de Janeiro: José Olympio, 1976.

NOVAES, Adauto (Org). O Olhar. In: CHAUI, Marilena. Janela da alma, espelho do mundo. São Paulo: Companhia das Letras. 1988.

Orfeu e Euridece. In: Infopédia [Em linha]. Porto: Porto Editora , 2003-2014. Disponível em <www.infopedia.pt>. Acessado em 20/08/2014.

PERSEU. In: Escola OnLine. Enciclopedia Escolar Britannica, 2014. Web. Disponível em: <escola.Britannica.com.br/article/482191/perseu>. Acessado em 20/08/2014

RUSSO, Renato. Índios. In: Legião Urbana. Produção: Mayrton Bahia. Jan/Março,1986.1 CD. Faixa $12(4 \min 23)$.

SANTIAGO, Silviano. Introdução à leitura dos poemas de Carlos Drummmond de Andrade. In: Poesia completa. Rio de Janeiro: Nova Aguilar S.A, 2002.

SÓFOCLES. Édipo Rei. Antígona. Trad. Jean Melville. São Paulo: Martin Claret, 2002.

VASCONCELLOS, Luís. A diferença entre o olhar e o ver. Jornal Aternativo. Disponível em: <http://somostodosum.ig.combr/ja/detalhes.asp?acao=artigos\&vid=33,1\&id=11777>. Acessado em $18 / 08 / 2014$.

VIANA, Carlos Augusto. Drummond: a insone arquitetura. Fortaleza: Editora UFC, 2003.

Recebido em 10 de julho de 2014 Aceito em 14 de agosto de 2014 